Globish (An English-Indonesian journal for English, Education and Culture )

Vol. 9 No.1 January 2020

P-ISSN: 2301-9913, E-ISSN: 2597-9132

DOI: http://dx.doi.org/10.31000/globish.v7i2

\title{
Analysis of Students' Problem in Writing Argumentative Text
}

\author{
${ }^{1}$ Mei Maria Meliana Situmorang, ${ }^{2}$ Elisabeth Hutabarat, ${ }^{3}$ Yesinta Panjaitan, ${ }^{4}$ Yenita \\ Sembiring
}

Faculty of Teacher Training and Education, University of Prima Indonesia

Jl. Danau Singkarak Gg. Madrasah, Sei Agul, Kec. Medan Barat,

Kota Medan, Sumatera Utara-Indonesia

Email: meyliana.situmorang@gmail.com, elisabethhutabarat280@gmail.com, yesintapanjaitan21@gmail.com, sembiring@gmail.com

\begin{abstract}
Writing is a unique ability that only some people might have, but it is unexpected that everyone also has the same ability to write something. Neither by arguing, although all can submit opinions or ideas about something, many of them are not able or not know how to argue properly and correctly. Aware of this, the author tries to find the constraints and problems experienced by the research subjects when they want to argue, especially through the text of the argumentation. Found that there were problems encountered when writing the argumentation text, it turns out that the obstacles experienced by the subject during the process of writing the argumentation text are very diverse, ranging from reasoning about something to lack of motivation to dare to argue. With the existence of this study we as authors and researchers hope that this research can be a reference for subsequent research and not only limited to that, the hope of the authors of this study can be a reference to the problems experienced by students'j in writing argumentative text.
\end{abstract}

Keywords: argumentative writing, writing argumentative text, argumentative text.

\section{INTRODUCTION}

Nowadays, everyone gradually realizes that writing ability has become an important skill to be mastered by those who want to be recognized in the global world. The act of writing makes the mind visible and can be transferred to other people.

Writing has been considered as one of the most important skills in learning a second or foreign language. The teaching paradigm of writing has gradually shifted from traditional product-oriented writing to process-oriented writing (Zamel, 1982; Ling, 1984a; Ling, 1986b; Hyland, 2003b; Harmer, 2004; Brown, 2007; Clark, 2012).

Concerning about writing, there are still some problems found in Indonesia. Alwasilah (2005) claims that skill of writing in Indonesia is the most ignore skill in language education. Then, writing habit in Indonesia is lower than reading habit (Khak, 2011). This situation is basically supported by the fact that Indonesia is in a far move to consider English as the foreign/second language in the country. Moreover, based on the data found in Scopus and Scimago, Indonesia only had 3.231 journal publications (Arradian, 2014). This number is not satisfying if it was compared to Malaysia's and Singapore's. Thus, as stated in Surat 
P-ISSN: 2301-9913, E-ISSN: 2597-9132

DOI: http://dx.doi.org/10.31000/globish.v7i2

Dirjen Dikti No. 152/E/T/2012, there is a rule from Directorate General of Higher Education of Indonesia which required students to write a research article and publish it in a journal as a requirement for graduation since August 2012.

\section{RESEARCH METHOD AND FINDINGS}

The study employs Classroom Action Research (CAR). Koshy (2005) defines action research as an enquiry which is carried out in order to understand, evaluate, and then modify educational program to improve educational practice. One of the proposed designs of action research is Classroom Action Research (CAR). The design is based on the consideration that the teacher as researcher attempts not only to solve the problem in the particular classroom, but also to improve the quality of teaching. One of the distinctive features of CAR design is the cycles to be implemented in the research; each of which consist of planning, acting, observing, and reflecting (Kemmis and Taggart, 2007).

The data were collected by using instruments, such as writing test and interview. After collecting the data, the researchers assessed and analyzed the students' test results using the scoring rubric and final score category provided in Table 1 and Table 2 below.

Table 1. The scoring rubric for argumentative essay assessment (Abbas, 2015, 2018)

\begin{tabular}{|c|c|c|c|}
\hline Aspects & Criteria & Scores & Category \\
\hline \multirow{5}{*}{$\begin{array}{c}\text { Content: } \\
\text { topic } \\
\text { development }\end{array}$} & Thorough development of topic & 20 & $\begin{array}{l}\text { Very } \\
\text { Good }\end{array}$ \\
\hline & Relevant to topic but lacks detail & 15 & Good \\
\hline & Inadequate development of topic & 10 & Fair \\
\hline & Does not show knowledge of topic & 5 & Poor \\
\hline & $\begin{array}{l}\text { Organize paragraph well and show good } \\
\text { coherence and chronological order }\end{array}$ & 30 & $\begin{array}{l}\text { Very } \\
\text { Good }\end{array}$ \\
\hline \multirow{4}{*}{$\begin{array}{l}\text { Organization: } \\
\text { unity, } \\
\text { coherence, } \\
\text { logical order }\end{array}$} & Loosely organized but ideas stand out & 25 & Good \\
\hline & Incoherent ideas and lacks logical sequencing & 20 & Fair \\
\hline & $\begin{array}{l}\text { Does not organize paragraph well and does not } \\
\text { show good coherence and chronological order }\end{array}$ & 15 & Poor \\
\hline & $\begin{array}{l}\text { Employ accurate and effective choice of } \\
\text { words/diction }\end{array}$ & 20 & $\begin{array}{l}\text { Very } \\
\text { Good }\end{array}$ \\
\hline Vocabulary: & Employ accurate diction, but not effective & 15 & Good \\
\hline
\end{tabular}

Analysis of Students' Problem in Writing Argumentative Text

${ }^{1}$ Mei Maria Meliana Situmorang, ${ }^{2}$ Elisabeth Hutabarat, ${ }^{3}$ Yesinta Panjaitan, ${ }^{4 Y}$ enita Sembiring 
P-ISSN: 2301-9913, E-ISSN: 2597-9132

DOI: http://dx.doi.org/10.31000/globish.v7i2

\begin{tabular}{|c|c|c|c|}
\hline \multirow[t]{3}{*}{$\begin{array}{l}\text { word choice/ } \\
\text { diction }\end{array}$} & $\begin{array}{l}\text { Employ lacks accuracy of diction, but meaning } \\
\text { not } \\
\text { obscured }\end{array}$ & 10 & Fair \\
\hline & $\begin{array}{l}\text { Errors in applying diction or word form, and } \\
\text { meaning } \\
\text { obscured }\end{array}$ & 5 & Poor \\
\hline & $\begin{array}{l}\text { Use correct grammar (pronouns, subject-verb } \\
\text { agreement, etc) }\end{array}$ & 20 & $\begin{array}{l}\text { Very } \\
\text { Good }\end{array}$ \\
\hline \multirow{4}{*}{$\begin{array}{l}\text { Grammar: } \\
\text { sentence } \\
\text { structure/ } \\
\text { construction }\end{array}$} & $\begin{array}{l}\text { Several errors of tense, pronouns, subject-verb } \\
\text { agreement, etc, but meaning not obscured }\end{array}$ & 15 & Good \\
\hline & $\begin{array}{l}\text { Major errors of tense, pronouns, subject-verb } \\
\text { agreement, etc, and meaning obscured }\end{array}$ & 10 & Fair \\
\hline & $\begin{array}{l}\text { No mastery of sentence construction and } \\
\text { dominated } \\
\text { by errors }\end{array}$ & 5 & Poor \\
\hline & Very little errors of mechanics & 10 & $\begin{array}{l}\text { Very } \\
\text { Good }\end{array}$ \\
\hline \multirow{3}{*}{$\begin{array}{l}\text { Mechanics: } \\
\text { spelling, } \\
\text { punctuation, } \\
\text { and } \\
\text { capitalization }\end{array}$} & $\begin{array}{l}\text { Few errors of mechanics, but meaning not } \\
\text { obscured }\end{array}$ & 9 & Good \\
\hline & $\begin{array}{l}\text { Many errors of mechanics, and meaning } \\
\text { obscured }\end{array}$ & 7 & Fair \\
\hline & Dominated by errors of mechanics & 5 & Poor \\
\hline
\end{tabular}

Table 2. The final score category (Abbas, 2015, 2018)

\begin{tabular}{c|c} 
Range of Final Scores & Category \\
\hline $86-100$ & Very Good \\
\hline $71-85$ & Good \\
\hline $56-70$ & Fair \\
\hline $10-55$ & Poor
\end{tabular}

\section{RESULT AND DISCUSSION}

Based on the results of written tests, and interviews, the researchers get a score from the tests conducted. The researchers got an average score of 59 which is the "Fair" result for the average student's ability to write argumentative texts and from this test, researchers can 
P-ISSN: 2301-9913, E-ISSN: 2597-9132

DOI: http://dx.doi.org/10.31000/globish.v7i2

find any subject that is an obstacle for students in writing argumentative texts. Neither with the results of interviews conducted.

Based on the results of research conducted following aspects of the assessment conducted on students in the ongoing research process:

\section{Content: topic development}

When starting research activities, researchers proposed several topics for students to choose voluntarily, while the topics given were "Dangers of Drugs", "Dangers of Mobile Use", and "Dangers of Waste Disposal".

Based on the topic given, students are asked to make a free essay that is argumentative in English in accordance with the given topic with a predetermined deadline of 20 minutes.

After 20 minutes have passed, students are not justified to continue writing activities. Students are asked to stop writing argumentative essays and collect them for later researched by researchers with subjective judgments based on table formulas. After the assessment process, it was found that generally every student / research subject could compose freely and express their thoughts very precisely based on the topic of their choice.

As far as research goes on, the researcher does not encounter any objective errors in the evaluation aspects of the given topic.

\section{Organization: unity, coherence, logical order}

The evaluation of essays writing argumentative texts that refer to aspects of organization / regularity between topics and aspects of the discussion is an assessment that is more to the relationship between topics and topics written by the author.

In the process, students are very understanding of what they write in the argument text but in certain conditions such as the regularity of the layout and paragraphs is not very good as well as aspects of the evidence for opinions and real facts that are not prominent to be said as argumentation text. But above all, in delivering ideas in the text, students are considered to be very good at doing it.

\section{Vocabulary: word choice / dictionaries}

The research subjects are Class X students of Prince Antasari High School which are domiciled in Indonesia which generally do not use Indonesian.

The assessment process during the research revealed that students were judged not to have enough knowledge of English vocabulary which in this process, they were asked to write their arguments in English.

As far as observations are made, students are very limited in the vocabulary they use in

Analysis of Students' Problem in Writing Argumentative Text 
P-ISSN: 2301-9913, E-ISSN: 2597-9132

DOI: http://dx.doi.org/10.31000/globish.v7i2

writing the argumentation text, so the choice of diction in the delivery of opinions seems like repeating the words that have been delivered.

In addition to these shortcomings, we as researchers also realize that in writing text arguments, students are still able to explain concisely the purpose and purpose of the writing they write.

\section{Grammar: sentence structure / construction}

Grammar is a provision for conveying the aims and objectives in a particular language. However, in its application in real life, grammar is often ignored so that grammar is considered to have no particular meaning that has a significant impact.

Neither is felt by students in the research process. Many students are very confused in understanding grammar, especially English grammar. In the writing process, students have something that they feel needs to be conveyed but in the process of writing it into argumentative texts in English, students are confused and doubtful about the grammar they should and actually use.

Doubts about the understanding and knowledge of English grammar that students have are assessed by us as researchers. Researchers found that there were limitations in understanding by students in understanding English grammar so that students were unable and hesitant to write their opinions in English.

Even so, during the research process, the researcher guides the students to remain focused in expressing their arguments in the text without caring about the right or wrong grammar they use.

As a result, although there were some errors in grammar during the process of writing argumentative texts, the researchers assumed students were sufficiently capable and able to express their opinions in argumentative texts.

5. Mechanics: spelling, punctuation, and capitalization

Spelling is part of the grammar and knowledge of English vocabulary; this is related to the understanding and knowledge of a word and the relationship between words that function to form a specific purpose.

During the research process students revealed that it was very difficult for them to start writing what arguments they would write in the argumentative text, "we are confused about what should be written here, I myself do not understand the procedures for writing and how to express opinions or arguments both in oral or written ". Researchers realize that students are overwhelmed and confused about the instructions given by researchers during this research activity. 
P-ISSN: 2301-9913, E-ISSN: 2597-9132

DOI: http://dx.doi.org/10.31000/globish.v7i2

Researchers found that one of the obstacles felt by students was the lack of student knowledge of understanding what is meant by "argument". Researchers realize this when they encounter students who do not immediately begin the process of writing argument texts when the "writing" instructions have been ordered. The observation results obtained by researchers revealed that students still lack understanding in making argumentative texts, and this is caused by a lack of understanding both structurally using argumentative text grammar to the contents of the text itself.

Furthermore, researchers also found that students' ability in mastering English vocabulary was still very low, even very far from being able to speak English, they were not accustomed to using English as their daily language which had an impact on their mentality that made them so do not want to understand and understand English, as well as their minimal English vocabulary knowledge. And the use of English grammar which is still largely not understood and understood its use. And most importantly, students are still foreign, and even very rarely given facilities to express their opinions / ideas in writing or verbally.

\section{CONCLUSIONS AND SUGGESTIONS}

The research model conducted by the researcher is Classroom Action Research (CAR), the researcher conducts research at a predetermined location that has previously obtained permission from the relevant government authorities in the local research area. Research activities carried out at the Prince Antasari College Foundation, grade 10 high school.

Before conducting research, researchers have previously designed the implementation method which will be used as a guide for researchers to carry out the activity process.

From the results of the research conducted, the researchers concluded that the problems faced by students in writing argumentative texts were numerous, ranging from the lack of understood vocabulary to how to express correct opinions / views both verbally and non-verbally.

Student facilities and infrastructure must be provided to them for their growth and development to become better students and as the successors to a nation that is far more dignified.

Realizing this, we hope that all related parties will pay more attention to students in the future so that this problem can be better resolved.

The researchers' great hopes for all parties can contribute to solving this problem. Likewise, with future researchers, I hope this research can be a reference to help solve problems related to writing argumentative text. 


\section{REFEREENCES}

Abbas, M. F. F. (2018). Assessing EFL students' ability in developing idea to organize academic essay. IOP Conference Series: Earth and Environmental Science 175(1), 012-074.

Borg, W.R., Gall, M.D. (1983). Educational Research: An Introduction, 4th Edition. London: Longman Inc.

Broadman, Cynthia A. (2008) Writing to Communicate (second edition), Pearson: Longman.

Brown, H Doughlas. (2001). Teaching by Principles; An Interactive Approach to Language Pedagogy, Second Edition, San Francisco: San Fransisco State University Press.

Boun, E. (2009). Argumentative essay. Retrieved June 6, 2017, from www.buowl.boun edu.

Ibrahim, M. E. E., Eljack, N. S. A., \& Elhassan, I. B. M. (2015). To what extent can argumentative essay writing help develop leaners' critical thinking. SUST Journal of Humanities, $16(4)$.

Lestari, Setyowati, S., Sukmawan, \& Latief, M. A. (2017). Solving the students' problems in writing argumentative essay through the provision of planning. A Journal of Culture, English Language, Teaching \& Literature, 17(1), 87- 102.

Mennens, H., B. Wikinson. (2002). Academic Writing Skill, Universiteit Maanstreit.

Yusuf, Rinasari. (2011). Error Analysis And Error Correction In Foreign Language Teaching.

Sanal, Fahrettin. (2007). Error Analysis Perspectives on Second Language Teaching Strategies. 